RESIDENT

\& FELLOW

SECTION

Section Editor

Mitchell S.V. Elkind,

MD, MS

Arun Antony, MD

Paul D. Larsen, MD

Address correspondence and reprint requests to Dr. Arun Antony, Department of Neurology, University of Nebraska Medical Center, 982045 Nebraska Medical Center, Omaha, NE 68198-2045 drarunraj@gmail.com

\title{
Teaching NeuroImages: Double cortex
}

"Two" is too many

Figure 1 Dual inversion recovery MRI

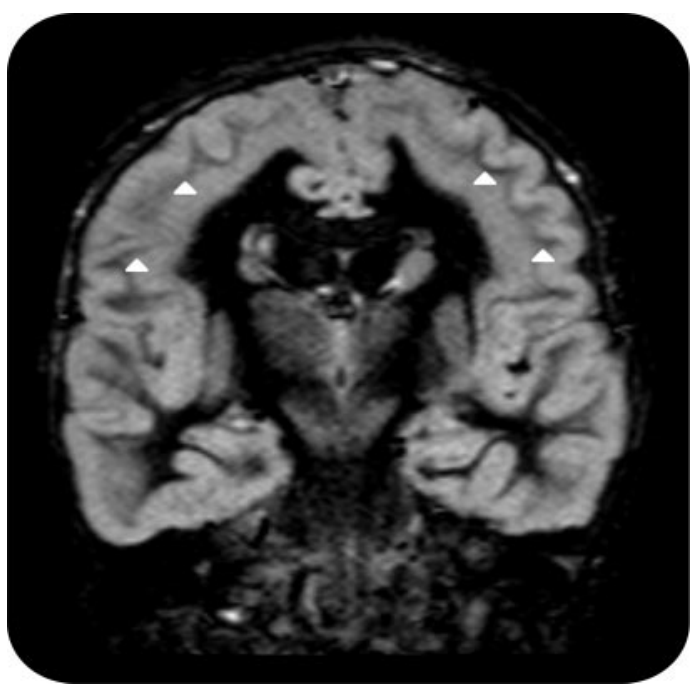

Coronal gray matter dual inversion recovery image shows thin white matter layer (arrowheads) separating the 2 layers of gray matter.

A 6-year-old ambidextrous girl born to unrelated parents presented with complex partial seizures and mental retardation. Her sister and mother had seizures and tested positive for the doublecortin gene mutation (DCX). EEG showed epileptiform discharges in the right occipital area and spikes over right frontal and left temporal areas. MRI showed subcortical band heterotopias, consisting of a linear band of gray matter below cortex (figure 1). She tested positive for the DCX mutation. Doublecortin is important for neuronal migration. ${ }^{1}$ In males, all neurons are affected, leading to lissencephaly, a smooth-appearing brain due to absent or abnormally thick gyri with neuronal disorganization and rudimentary cortex. In females, affected neurons migrate

\section{Figure 2 Axial T1 MRI}

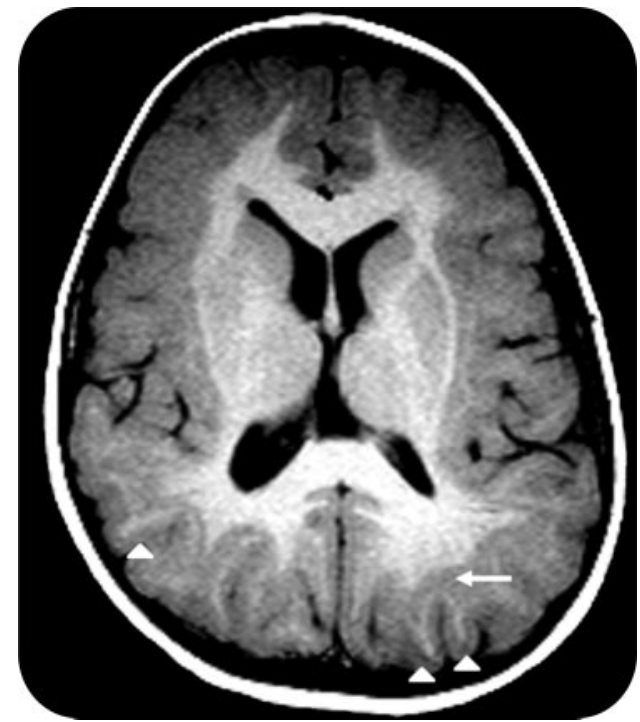

Axial T1 image shows band heterotopia (arrow) with white matter separating the band from cortex and thickened gray matter (arrowheads) which consists of cortex and underlying band heterotopia.

to the subplate region, forming band heterotopia (figure 2), while unaffected neurons migrate to form the cerebral cortex. ${ }^{2}$ There can be a continuum between band heterotopia and lissencephaly depending on the degree of gene expression.

\section{REFERENCES}

1. Gleeson JG, Minnerath SR, Fox JW, et al. Characterization of mutations in the gene doublecortin in patients with double cortex syndrome. Ann Neurol 1999;45: 146-153

2. Barkovich AJ, Kuzniecky RI, Jackson GD, et al. A developmental and genetic classification for malformations of cortical development. Neurology 2005; 65:1873-1887. 


\title{
Neurology
}

\author{
Teaching NeuroImages: Double cortex: "Two" is too many \\ Arun Antony and Paul D. Larsen \\ Neurology 2010;75; e8 \\ DOI 10.1212/WNL.0b013e3181e8e6e9
}

This information is current as of July 19, 2010

\section{Updated Information \& Services}

\section{References}

Subspecialty Collections

Permissions \& Licensing

Reprints including high resolution figures, can be found at:

http://n.neurology.org/content/75/3/e8.full

This article cites 2 articles, 1 of which you can access for free at: http://n.neurology.org/content/75/3/e8.full\#ref-list-1

This article, along with others on similar topics, appears in the following collection(s):

All Epilepsy/Seizures

http://n.neurology.org/cgi/collection/all_epilepsy_seizures All Pediatric

http://n.neurology.org/cgi/collection/all_pediatric

Complex partial seizures

http://n.neurology.org/cgi/collection/complex_partial_seizures

Cortical dysplasia

http://n.neurology.org/cgi/collection/cortical_dysplasia

MRI

http://n.neurology.org/cgi/collection/mri

Information about reproducing this article in parts (figures,tables) or in its entirety can be found online at:

http://www.neurology.org/about/about_the_journal\#permissions

Information about ordering reprints can be found online:

http://n.neurology.org/subscribers/advertise

Neurology ${ }^{\circledR}$ is the official journal of the American Academy of Neurology. Published continuously since 1951, it is now a weekly with 48 issues per year. Copyright. All rights reserved. Print ISSN: 0028-3878. Online ISSN: 1526-632X.

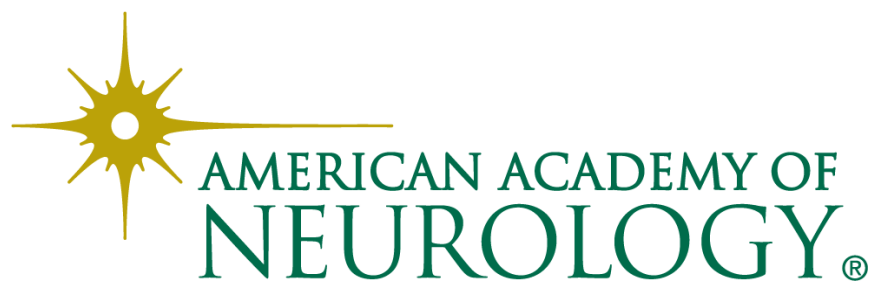

